\title{
Novel Medical Treatment Modalities of Endometriosis
}

\author{
Endometrioziste Yeni Medikal Tedavi Yöntemleri
}

\section{Gülsüm Uysal', Fulya Çağlı1', Hüseyin Aksoy², Ülkü Aksoy', Bașak Cıngıllıoğlu' , Eda Karakıııç', Gökhan Açmaz'}

${ }^{1}$ Kayseri Education and Research Hospital, Department of Obstetrics and Gynecology, Kayseri, Turkey; ${ }^{2}$ Kayseri Military Hospital, Department of Obstetrics and Gynecology, Kayseri, Turkey

\begin{abstract}
Endometriosisis a very common gynecological condition causing infertility and pelvic pain affecting $6 \%-10 \%$ of women at their reproductive ages. The prevalence is $20 \%-50 \%$ and $20 \%-70 \%$ in infertile women and women with chronic pelvic pain, respectively. The treatment of endometriosisis is always challenging for healthcare professionals and there is no curative treatment option for endometriosis.

The treatment options for endometriosis can be classified as medical, surgical or combinations of the two approaches. Different medical agents exist for treatment of endometriosis. The most commonly used of these medical agents are non-steroidal antiinflammatory drugs, analgesics, gestagens or their derivatives, combined oral contraceptive pills, and more recently the levonorgestrel intrauterine system. Although there are numerous treatment options, available pharmacological treatment options in endometriosis are not fully satisfactory. Numerous new medical treatment agents are currently being tested in clinical trials in different phases. The purpose of the present review is to discuss the new medical treatment modalities in endometriosis.
\end{abstract}

Key words: endometriosis; medical treatment; pelvic pain

\section{ÖZET}

Endometriozis üreme çağındaki kadınların \%6-10'unu etkileyen infertilite ve pelvik ağrıya neden olan yaygın görülen jinekolojik bir durumdur. Infertil kadınların \%20-50'sinde, kronik pelvik ağrısı olan kadınların ise \%20-70'inde görülür. Endometriozis tedavisi her zaman klinik açıdan zor bir durum olmakla beraber tam șifa ile sonlanan bir tedavi seçeneği yoktur.

Endometriosis tedavisi medikal ve cerrahi ya da her ikisinin beraber kullanımı șeklinde sınıflandırılabilir. Tedavide birçok farklı medikal ajanlar kullanılabilir. En sık kullanılan medikal ajanlar non-sterod antiinflamatuar ilaçlar, analjezikler, gestajen ve türevleri, kombine oral kontraseptifler ve son zamanlarda levonorgestrel içeren rahim içi araçlardır. Kullanımda olan birçok farmakolojik tedavi seçeneği olmasına rağmen, hiçbiri tam anlamıyla bașarı sağlamamaktadır.

Uzm. Dr. Gülsüm Uysal, Kayseri Eğitim ve Arașttrma Hastanesi, 38100 Kayseri, Türkiye, Tel.03523382149Email.gulsumaykut@yahoo.com Geliş Tarihi:09.01.2015 • Kabul Tarihi: 15.04.2015
Çeșitli yeni medikal tedavi ajanları klinik denemelerden geçmektedir. Bu derlemenin amacı endometriosis tedavisinde yeni medikal tedavi yöntemlerini tartıșmaktır.

Anahtar kelimeler: endometriyozis; medikal tedavi; pelvik ağrı

\section{Introduction}

Endometriosis, defined as the presence of tissue that is morphologically and biologically similar to endometrial glands and stroma in locations outside the uterus. It is a common disease affecting up to $6-10 \%$ of women at their reproductive ages ${ }^{1-3}$.

Women with subfertility and pelvic pain have prevalence rates ranging from $20 \%$ to $50 \%$ and from $20 \%$ to $70 \%$, respectively ${ }^{1-3}$. Ectopic implants of endometriosis are primarily located in pelvic organs; ovaries, anterior and posterior cul de sacs, broad ligaments, uterosacral ligaments, uterus, and fallopian tubes. Endometriosis can be defined as an estrogen-dependent chronic inflammatory disease that causes a broad spectrum of symptoms; however, the cardinal clinical features are infertility and pelvic pain ${ }^{3}$.

The definitive pathogenesis of endometriosis remains unclear, but several theories explaining different aspects and locations of disease have been proposed. Retrograde menstruation and coelomic metaplasia theories are the most widely accepted theories ${ }^{4}$. Although the exact pathogenesis of endometriosis is not completely elucidated, it is currently accepted that endometriosis is a complex and multifactorial condition of uncertain etiology. Hormonal, immunological, inflammatory, genetic, environmental, and possibly even lifestyle factors are implicated in the pathophysiology of the disease $e^{4-9}$. 
The management of women with endometriosis is always challenging for healthcare professionals. There is no absolute cure for endometriosis. Treatment may be medical or surgical. The goal of surgical treatment of endometriosis is to remove endometriotic implants and scar tissue. Surgical intervention can be either conservative or definitive.

Medical treatment of endometriosis ranges from symptomatic control to treatments that aim to suppress the ovarian production of estrogen. Current medical treatment options include non-steroidal anti-inflammatory drugs (NSAIDs) and analgesics for symptomatic pain control, application of gestagens or their derivatives and combined oral contraceptive pills (COCPs) to suppress ovulation, gonadotrophin-releasing hormone agonists (GnRH) or GnRH antagonists, and danazol for menopausal simulation. More recently the levonorgestrel intrauterine system with/without the combination of the previous treatment options are available ${ }^{10-13}$. However, the present pharmacological treatment options in endometriosis are not fully satisfactory. Numerous new medical treatment agents are currently being tested in clinical trials in different phases. The purpose of the present review is to discuss the new medical treatment modalities used in the management of endometriosis.

\section{Current New Medical Agents in Endometriosis Treatment}

\section{Progesterone Receptor-Binding Molecules (PRBM)}

With a view to blocking or modifying downstream effects, progesterone receptor modulators interact with progesterone receptor. PRBM decrease not only progesterone but also estradiol. Progesterone antagonist mifepristone (RU-486) and the selective progesterone receptor modulators asoprisnil and CDB4124 (a 21-substituted-19-nor-progestin) have been proposed as therapeutic agents for endometriosis ${ }^{14,15}$. Mefipristone is reported to have benefits in some patients in terms of reduced pain and regression of lesions ${ }^{16-18}$.

\section{Selective Estrogen Receptor $\beta$-agonist}

Inflamation and macrophages are known to lead to the over expression of estrogen receptor-a (ER-a) and estrogen receptor-b (ER-b) in women with endometriosis. Estrogen receptor-a agonists mediate most of the classic effects of estrogen. However, ER-b-selective agonists possess anti-inflammatory properties ${ }^{19}$. In a mouse model of endometriosis, ERB-041 induced complete regression of lesions in $40 \%$ to $75 \%$ of animals from different series, and recovered lesions expressed ER-a, but not ER-b-mRNA ${ }^{20}$.

\section{Selective Estrogen Receptor Modulators (SERMs)}

Development and progression of endometriosis should be interfered with the drugs blocking the estrogen receptors. Stratton et al. showed in humans that endometriosis related pelvic pain is likely to be treated by raloxifene, which means that, SERMs may act in the modulation of lesions and chronic pelvic pain like an estrogen ${ }^{21}$.

\section{New Promising Groups of Drugs Tested in Animals and Humans}

\section{Tumor Necrosis Factor Alpha (TNF- $\alpha$ ) Blockers}

The inflammatory cytokine TNF- $\alpha$ with an increase of peritoneal fluid in women with endometriosis compared with women without endometriosis, appears to play a key role in the pathogenesis and progression of endometriosis ${ }^{22}$. Tumor necrosis factor alpha-blocking agent etanercept can cancel out the in vitro proliferative effect of TNF- $\alpha$ on endometriotic cells ${ }^{23}$. Anti TNF- $\alpha$ therapy has been showed to prevent the development of induced endometriosis in both rats and baboons, but human data is not available. Inhibition of TNF- $\alpha$ on endometriosis-associated subfertility has not yet been evaluated in preclinical models, and only one human study has been published ${ }^{24,25}$.

Etanercept: Etanercept which acts as a TNF inhibitor is a drug that is mainly used in treating autoimmune diseases. The effects of etanercept on endometriotic implants were evaluated in randomized controlled studies in a rat model. Treated animals showed significant changes in the volume of lesions, histopathologic scores, and molecular parameters such as serum levels of vascular endothelial growth factor (VEGF), interleukin-6 (IL-6), and TNF- $\alpha^{26,27}$. Barrier et al. suggested that etanercept effectively reduced the amount of spontaneous active endometriosis in the baboons tested in a randomized, controlled, blinded study that included 12 animals received either etanercept or placebo $^{28}$.

Anti Tumor Necrosis Factor Alpha-monoclonal antibody (TNF- $\alpha-\mathbf{m A b})(\mathbf{c} 5 \mathrm{~N})$ : The efficacy of $c 5 N$, a specific anti-TNF- $\alpha-m A b$, in the reduction of established lesions of experimental endometriosis induced 
in baboons was also tested in a randomized controlled study $^{29}$. No impact on the menstrual cycle was found. In another study, anti TNF- $\alpha-m A b$ treatment significantly reduced the extent of endometriosis in baboons with induced endometriosis ${ }^{30}$.

\section{Nuclear Factors $k B(N F-k B)$ Inhibitors}

The NF-kB peptide family comprises the most important group of transcription factors involved in the inflammatory and immune responses seen in endometriosis. Nuclear factor $\mathrm{kB}$ is activated by cytokines such as TNF- $\alpha$ and IL-1b. It binds to DNA to determine favoring cell proliferation and inhibiting apoptosis in various cell types including endometrial and endometriotic cells ${ }^{31-34}$.

Cell proliferation, motility, adhesion, and invasion abilities were significantly reduced, and apoptosis was increased in vitro ${ }^{32-34}$. NF-kB suppression was useful in reducing endometriosis establishment and progression in animal models and diminishing endometriosis-associated symptoms in women.

\section{Statins}

Statins are molecules that lower cholesterol synthesis by blocking the conversion of 3-hydroxy-3-methylglutaryl-coenzime A (HMG-CoA) into mevalonate, a cholesterol precursor. They also have been demonstrated to inhibit cell proliferation in a number of biologic systems, such as in vitro cultures of eutopic endometrial stromal cells, by mechanisms that have not been clarified, yet ${ }^{35}$. Several clinical trials have demonstrated that statins are effective for both the primary and secondary prevention of coronary artery diseases. In addition, statins have been shown to have anti-inflammatory and anti-angiogenic activity ${ }^{36}$.

Lovastatin: Esfandiari et al. suggest that lovastatin, an HMG-CoA reductase inhibitor, can negatively modulate both cell proliferation and angiogenesis in a concentration dependent manner. Lovastatin was also capable of inhibiting stromal cell invasion and angiogenesis in a three dimensional fibrin matrix culture sys$\mathrm{tem}^{37}$. It is a potent inhibitor of expression of VEGF, which is most probably the mechanism behind the diminished blood-vessel formation. There are reports showing that statins can reduce endothelial cell proliferation and migration ${ }^{38}$.

Other Statins (Simvastatin, Atorvastatin, Endostatin): Simvastatin added a dose dependent reduction in the number of viable cells and cell adhesion as well as increased apoptosis in culltures of human endometriotic stromal cells (hESCs). Statins have both preventive and therapeutic effects on endometriosis ${ }^{39}$. Atorvastatin significantly inhibited the expression of inflammatory and angiogenic genes cyclooxygenase-2 (COX-2) and VEGF, and increased the expression of anti-inflammatory genes such as peroxisome proliferator-activated receptor $\mathrm{g}$ (PPAR-g) in cultures of both eutopic stromal and human endometriotic stromal cells ${ }^{40}$. Yilmaz et al. tested atorvastatin on peritoneal model of endometriosis in rodents. However, it has achieved conflicting results in endometriosis-like lesions: in one study there was a statistically significant reduction in the lesions area, but in another study only intraperitoneal atorvastatin was able to reduce their weight and volume significantly ${ }^{41}$.

\section{Melatonin}

A documented powerful free radical scavenger and broad-spectrum antioxidant molecule, melatonin, which is the major secretory product of the mammalian pineal gland, has emerged as an important analgesic, antioxidant, and anti-inflammatory agent. It caused regression and atrophy of endometriotic lesions in rats. It also, had a more pronounced regression of surgically induced endometriotic foci when compared with letrozole in a rat model $^{42,43}$. The possible effect of melatonin on the regulation of endometriosis was tested by interfering with matrix metalloproteinase activity in the mice model. The preventive and therapeutic action in endometriosis-like lesions was confirmed, with an increased apoptotic index ${ }^{44,45}$.

\section{Mitogen-Activated Protein Kinase (MAPK) Inhibitors}

P38 MAPK inhibitors (FR167653 and SB203580): P38 mitogen-activated protein kinase (p38 MAPK) is an intracellular signal-transducing molecule, playing an important role in the regulation of a variety of inflammatory responses, including expression of proinflammatory cytokines, leukocyte adhesion and chemotaxis ${ }^{46}$. Activation of p38 MAPK may be involved in the pathogenesis of endometriosis. Specific inhibitors of the p38 MAPK inhibitors SB203580 and FR167653 were tested in a murine model of endometriosis. Statistically significant reductions in p 38 MAPK phosphorylation and in the weight and size of lesions were observed in the peritoneal fluid and cells of treated rodents ${ }^{47,48}$. 


\section{Immunomodulators}

Changes in both cell-mediated and humoral immunity in rhesus monkeys and in women with endometriosis have been observed. Investigators noticed reduced immune response to autologous endometrial tissue such as: decreased $\mathrm{T}$ cell-mediated cytotoxicity, decreased $\mathrm{T}$ cell-dependent B-cell proliferation and decreased lymphocytic infiltration in response to intradermal injection of autologous endometrial antigen $s^{49,50}$.

Decreases in natural killer (NK) cell activity, dysfunction of $\mathrm{T}$ lymphocytes, infiltration of macrophages, and aberrant concentrations of immune-related cytokines were observed in the peritoneal fluid of affected women ${ }^{51}$.

IL-12: Peritoneal administration of IL-12 enhanced the cytotoxicity of splenic NK cells and decreased the development of endometriosis-like lesions in rats with induced endometriosis ${ }^{51}$.

Imiquimod: Imiquimod, an imidazoquinoline, stimulates monocytes, macrophages, and dendritic cells to produce cytokines which are important inducers of cell mediated immunity. It is currently used as a topical immune modifier for the treatment of condylomata acuminata $^{52}$.

Leflunomide: Leflunomide, used mainly in rheumatoid arthritis, has antiinflammatory, antipyretic, and analgesic effects. At high doses, its active metabolite A77 1726 suppresses IL-1 and TNF-a production ${ }^{53}$.

Levamisole: Levamisole is currently used as an antihelminthic drug and as well as an adjuvant in the treatment of colorectal adenocarcinomas. Moreover, this molecule can stimulate the formation of antibodies to various antigens, enhance the cellular immune response provided by $\mathrm{T}$ cells, and potentiate monocyte, macrophage, and neutrophil functions ${ }^{54}$. All these agents were shown to significantly reduce the volume of endometriosis-like lesions, with regression of both glands and stroma, when compared with controls ${ }^{52-54}$. Ceyhan et al. have shown that treatment with immune modulators or aromatase inhibitors in an experimental model have the potential to regress endometriotic implant size ${ }^{55}$.

Temsirolimus: Temsirolimus is one of the mammalian target of rapamycin (mTOR) inhibitors that are currently available for clinical use and has been approved for the treatment of renal cell carcinoma ${ }^{56}$. Mammalian target of rapamycin inhibition by temsirolimus alters the phenotype in both in vitro and in vivo mouse models of deep infiltrating endometriosis ${ }^{56}$. Blockage of the mTOR pathway may be considered a novel line of research in the treatment of endometriosis.

\section{Matrix Metalloproteinase (MMPs) Inhibitors}

Matrix metalloproteinases are a family of endopeptidases that play a role in the degredation and turnover of extracellular matrix proteins. Their action is regulated by specific tissue inhibitors called tissue inhibitors of metalloproteinases (TIMPs). Derangement of MMP regulation is considered to be a critical factor in the development of pathologic conditions such as endometriosis ${ }^{57}$. The mechanism for these actions, as well as many additional regulators of the system, is complex and reviewed elsewhere ${ }^{44,58}$.

ONO-4817: The MMP inhibitor ONO-4817 was used in the mouse model to determine the development of experimental adenomyosis ${ }^{58}$. During the use of MMP inhibitors in the prevention and treatment of endometriosis, care must be taken regarding the side effects of excessive TIMP activity on reproduction. In the rat model of endometriosis, recombinant TIMP-1 administration was associated with reproductive $a b$ normalities such as fewer ovarian follicles and fewer and altered zygotes ${ }^{59}$.

\section{Apoptotic Agents}

Previously published studies comparing patients with endometriosis with normal women showed decreased apoptotic index in ill ones ${ }^{60}$. Overexpression of antiapoptotic protein (Bcl-2) was found in stromal cells of proliferative eutopic endometriosis compared to normal endometrium ${ }^{61}$.

Pro-apoptotic protein (Bax) expression was found to be absent in proliferative endometrium resulting in decreased apoptosis during establishment of endometriosis $^{61}$. Random expressions of Fas were found in eutopic and ectopic endometrial tissues, suggesting less involvement of Fas as an apoptotic regulator $^{62}$. Expression of FasL (Fas Ligand) in endometrial stromal cells may induce apoptosis in local immune cells, e.g. macrophage, lymphocyte to promote early endometriosis development ${ }^{63}$. Reports have also demonstrated the involvement of $\mathrm{p} 53$, a potent inducer of apoptosis, during malignant transformation of endometriosis in human, where p53 staining was found to be negative in benign endometriotic cysts but positive in malignant cysts ${ }^{64}$. 
Curcumin: Curcumin, a natural polyphenolic compound used in popular medicine as an anti-inflammatory agent, is also reported to be a NF-kB inhibitor and to induce p53-mediated apoptosis ${ }^{65}$. Curcumin was capable of both preventing and treating induced endometriosis in rodents ${ }^{66}$. With the highest oral curcumin dose in use ( $150 \mathrm{mg} / \mathrm{kg}$ per day), ectopic glandular tissue disappeared, and VEGF expression and microvessel density were proportionately reduced. This findings suggest therapeutic potential of curcumin as an antiendometriotic drug ${ }^{66}$.

\section{Anti-angiogenetic Agents}

It is now well known that angiogenesis and the balance of local pro\&anti-angiogenic factors play a key role in the organisation and growth of endometriotic lesions. Most prominent angiogenic factors in endometriosis are cytokines (IL-1 $\beta$, IL-6, IL-8), VEGF, TNF- $\alpha$ and hormones (estrogen and progesterone). In endometriosis, VEGF is known as the most prominent and most studied proangiogenic factor and it is showed that VEGF is the main stimulus for angiogenesis and increased vessel permeability ${ }^{67}$. Various factors such as estrogen and progesterone, hypoxia, prostaglandin E2, IL-1 and IL-6 enhance VEGF expressions and concentrations. Donnez et al. discovered higher VEGF in the peritoneal fluid and lesions of endometriosis patients compared to controls ${ }^{68}$. It has been thought that inhibition of VEGF may be a novel therapeutic approach for the treatment of endometriosis ${ }^{69}$.

\section{Angiogenesis Inhibitors (VEGF Blocking):} Angiogenesis inhibitors can be divided into two different groups; the drugs in first group block proangiogenic cytokines or inhibit the interaction of cytokines with their cellular receptors; and the drugs in second group have a direct inhibitory effect on the endothelial cells ${ }^{70}$. We will review these angiogenesis inhibitor drugs as new future treatments.

Endostatin: Endostatin isolated from conditioned media of hemangio-endothelioma cells, is an endogenous angiogenesis inhibitor. Becker et al. showed inhibiting effects of endostatin in endometriosis lesions of mouse model with both continuous and twice daily subcutaneous doses. It was suggested that endostatin did not have any negative effect on reproduction system ${ }^{71}$. An analogous molecule called endostar has recently been tested in phase III studies for cancer in China ${ }^{72}$. In future studies, endostatin may be a new promising hope of treatment of endometriosis.

Angiostatin: Derived from Lewis Lung carcinoma cells, a proteolytic fragment of plasminogen angiostatin acts directly on activated endothelial cells by inhibition of ATPase activity of endothelial cells ${ }^{73}$. Angiostatin also inhibits activation of intrinsic and extrinsic apoptosis pathways and VEGF which is elevated in the peritoneal fluid of endometriosis patients $^{74}$. Angiostatin gene transfer in a mouse model of endometriosis was studied. A decrease in the number, size, and density of blood vessels and more importantly, endometriosis eradication were established in all treated mice within 18 days $^{75}$. Direct injection of angiostatin into macaque preovulatory follicles neither altered ovarian morphology nor had an effect on serum progesterone levels ${ }^{76}$.In addition, in clinical phase I trials angiostatin was well tolerated ${ }^{77}$.

Anginex: It has a synthetic angiogenesis inhibitor role in blocking proliferation, adhesion and migration, and in triggerring apoptosis of endothelial cells. Nap et al. showed that anginex reduces the number of established endometriotic lesions in a mouse model of endometriosis ${ }^{78}$. However, the effect of anginex upon reducing endometriosis lesions was modest and it has not been used in clinical trials.

Dopamin Agonists (Cabergoline and Quinagolide): Dopamine agonists cabergoline and quinagolide inhibit VEGF action and angiogenesis. Their effects have not been fully understood. In a human pilot study with 10 hyperprolactinemic patients who had severe endometriosis, it was showed that all noted endometriosis lesions disappeared in two out of nine patients ${ }^{79}$. Also dopamin agonists are being used in preventing ovarian hyperstimulation syndrome via inhibition of VEGF ${ }^{80}$.

\section{Other VEGF-inhibitors}

TNP-470: A synthetic analogue fungus derived from antibiotic fumagilin, TNP-470 is an effective antiangiogenetic agent. Unfortunately, it has inhibitor effects upon maturation of endometrium and corpus luteum and impairs neurons ${ }^{81}$.

Rapamycin: It is a kind of bacterial macrolide with antifungal and immunosuppressant activity and is used in organ transplanted patients 
against rejection. The inhibitor effects of rapamycin were showed in a hamster model of induced endometriosis ${ }^{82}$.

SU5416 and SU6668: In an induced endometriosis study on rodents, it was showed that both VEGF2 inhibitors SU5416 and SU6668 had significant blocking effects on vessel formation and both reduced the size of lesions ${ }^{83}$.

\section{Drugs Effecting Peroxisome Proliferator-activated Receptors (PPAR)}

Thiazolidinediones: Thiazolidinediones (TZDs) are insulin sensitizers and clinically used antidiabetic drugs, that activate PPAR. PPAR- $\gamma$ may be an important factor in endometriosis as a new class of immunomodulators found in endometrial epithelial and stromal cells ${ }^{84}$. They have also been shown to decrease aromatase activity in cultured human granulosa cells ${ }^{85}$. In a baboon model of established endometriosis, PPAR- $\gamma$ agonist rosiglitazone was given 2 $\mathrm{mg} /$ day orally and after therapy significant decrease in size of endometriotic lesions was seen ${ }^{86}$. In reported human case series rosiglitazone has also reduced pain ${ }^{87}$. Although TZDs are clinically used drugs that makes them attractive options for use in clinical trials in endometriosis in the future, they have unwanted side effects.

Fenofibrate: Fenofibrates are used in dyslipidemia and atherosclerosis which is an inflammatory disease involving the immune response. A PPAR- $\alpha$ agonist fenofibrate showed significant reduction in established endometriosis implants in a rat model of study ${ }^{88}$.

\section{Metformin}

Metformin is an insulin sensitizer agent from the biguanid family which is widely used in the treatment of diabetes and polycyctic ovary syndrome. The antioxidant properties and benefical effects upon inflammatory response has been showed ${ }^{89}$. In two rat studies, in which abdominal endometriosis was induced, significant reduction of size and volume of endometriotic lesions were shown compared to controls ${ }^{90}$. VEGF and matrix MMPs-9 levels were detected significantly lower in treated lesion in rats ${ }^{91}$. In a study where endometriosis diagnosed using laparoscopy in infertile patients treated with metformin for 3 to 6 months, the levels of VEGF, IL-6 and IL-8 were significantly decreased after metformin therapy compared to controls ${ }^{92}$.

\section{Hyaluronic Acid (HA)}

Molecules that prevent implantation of endometrial tissues could be used for treatment. Although there is little known about mechanisms of tissue implantation in endometriosis, HA which has already been used clinically to prevent adhesion formation after abdominopelvic surgery could be a new candidate for treatment ${ }^{93}$. Hyaluronic acid reagent suppressed endometriotic lesion formation in a mouse model $^{94}$.

\section{Pentoxifylline (PTX)}

As a kind of methylxanthine with antiinflammatory and antioxidant properties, pentoxifylline, a phosphodiesterase inhibitor, has been used for many years in the treatment of peripheral vascular diseases. The drug is known to suppress cytokine production, mainly TNF- $\alpha$ in macrophages which induces VEGF production ${ }^{95}$. In vitro animal models showed that the number, volume and weight of lessions were significantly reduced after PTX injection to endometriotic tissue $^{96}$. Several human studies have evaluated PTX orally after surgery to limit recurrence of signs and symptoms of endometriosis, but no significant impact on pregnancy rate and recurrence of symptoms was noted ${ }^{97}$.

\section{Anti-oxidants}

Catalase, superoxide dismutase and glutathione peroxidase/reductase are enzymatic antioxidants. Vitamin C, A, E and pyruvate and glutathione are also classifed as non-enzymatic antioxidants. Lower antioxidant levels were found in the peritoneal fluid of infertile women with endometriosis ${ }^{98}$. Vitamin C (1000mg, 2 tabletsof $500 \mathrm{mg}$ each) and vitamin $\mathrm{E}$ (1200 IU, 3 capsules of $400 \mathrm{mg}$ each) therapy given for two months reduced pelvic pain in women with endometriosis $^{99}$. In an endometriosis established animal model study $\mathrm{N}$-acetyl-L-cysteine (NAC) was administered by gavage with $100 \mu \mathrm{L}$ of a $10 \mathrm{mg} / \mathrm{mL}$ solution in water. At the end of the treatment COX-2 gene expression and MMP-9 activity were decreased. NAC reduces endometrial mass, by changing cell behavior from proliferation to differentiation and decreases tissue inflammation and cell invasion ${ }^{100}$. Although the antioxidant vitamins and drugs with antioxidant effects have been shown to have some benefits in endometriosis, further larger studies are needed because of lack of statistical results and small numbers in current attending studies. 


\section{Histone Deacetylase Inhibitors (HDACI)}

Because of reduced susceptibility to apoptosis in endometriosis, demethylation agents and histone deacetylase inhibitors (HDACI) might be used in treatment. Ectopic endometriotic cells survive with the help of down regulation of genes involved in apoptosis ${ }^{101}$.

Romidepsin: Romidepsin, one of the HDACI, reduced transcriptal activity of VEGF, inhibited cell proliferation and significantly increased apoptosis ${ }^{102}$. Originally isolated from culture of Cromobacterium violaceum, romidepsin induces $\mathrm{p} 21$ gene expression that negatively regulates cell cycle progression and is relevant for inhibition of tumaral cell proliferation. P21 and p27 may also play a role in endometriosis ${ }^{103}$.

Tricostatin A and Valproic acid: Histone Deacetylase Inhibitors, Tricostatin A and valproic acid, up-regulate p21 in endometriotic cells. Both of them reduced the size of lesions and releaved hyperalgesia in the murine model of endometriosis ${ }^{104}$. In a pilot study, three patients with endometriosis and adenomyosis were given a dose of $1000 \mathrm{mg} /$ day valproic acid for 3 months. At the end of the therapy, a complete relief of pain in all cases was detected and one participant's uterine size was reduced ${ }^{105}$. Anti cancer agents can be an option for treatment of endometriosis as a benign disease in the future.

\section{Flavanoids}

Structurally similar estrogen like molecules isoflavonoids which bind to estrogen receptors, competing with estradiol and having anti-estrogenic effects, might be a treatment option in patients with endometriosis.

Puerarin: Puerarin is an isoflavonoid derived from Pueraria Lobata, a Chinese medicine known as Gegen which improves pain and improves the quality of life in endometriosis. Significant reduction of lesions was shown in peritoneal endometriosis induced in rats treated with puerarin. Besides reducing estrogen levels puerarin needs high doses to affect, lowers blood calcium and causes osteoporosis ${ }^{106}$.

Epigallocatechin-3-gallate: Epigallocatechin-3-gallate (EGCG) the major chemical component of green tea, is a flavonoid which has antioxidant, proapoptotic and angiogenic effects. There are only three animal model studies in the literature showing that EGCG significantly inhibited size, area, and numbers of the lesions, and the size of micro vessels ${ }^{107,108}$.

\section{Discussion}

There are many new treatment modalities tested in humans and animals. To date, the most extensively used medications in treatment of endometriosis are still COCP and GnRH agonists. Their effectiveness has been clearly established, but especially side effects of GnRH agonists limit their use. Many exciting new classes of agents to treat endometriosis are presently being investigated. Most of these new medications have shown great efficacy in animal trials. Selective estrogen and progesterone receptor modulators are the most promising agents that are currently available on the markets and that cause less side effects than other drugs currently available. New anti-angiogenetic agents, angiogenesis inhibitors and immunomodulators may provide a great improvement in treatment of endometriosis.

The evidence related with new experimental drugs is limited and larger double-blinded, randomized, placebo-controlled clinical trials of these new agents in humans are needed. On the other hand, the timing of treatment (to start as neo-adjuvant therapy or in postoperative period?) or the safe duration for treatment is unclear. It has been thought that inhibition of VEGF may be a novel therapeutic approach for the treatment of endometriosis.

Gene therapy applications such as viral vectors used for gene transfer have shown to promise in several preclinical studies. Anti cancer agents can be an option for treatment of endometriosis as a benign disease in the future. New medical agents for the treatment of endometriosis targeting both hormonal and non-hormonal pathways are promising, but their efficacy and safety are needed to be established in randomized human trials before they can be used in routine clinical practice.

\section{References}

1. Zhao SZ, Wong JM, Davis MB et al. The cost of inpatient endometriosis treatment: an analysis based on the Healthcare Cost and Utilization Project Nationwide Inpatient Sample. Am J Manag Care 1998;4:1127-34.

2. Gao X, Outley J, Botteman M et al. Economic burden of endometriosis. Fertil Steril. 2006; 86:1561-72.

3. Juares M,Tomas L. Endometriosis risk factors, symptoms and management. NewYork: Nova 2013 Chap 3, p77-111.

4. Burney RO, Giudice LC. Pathogenesis and pathophysiology of endometriosis. Fertil Steril 2012;98:511-9. 
5. Augoulea A, Alexandrou A, Creatsa M et al. Pathogenesis of endometriosis: the role of genetics, inflammation and oxidative stress. Arch Gynecol Obstet 2012; 286:99-103.

6. Murphy AA, Palinski W, Rankin S et al. Evidence for oxidatively modified lipid-protein complexes in endometrium and endometriosis. Fertil Steril 1998; 69:1092-4.

7. Kyama CM, Mihalyi A, Simsa P et al. Role of cytokines in the endometrial-peritonealcross-talk and development of endometriosis. Front Biosci (Elite Ed) 2009;1:444-54.

8. Seli E, Berkkanoglu M, Arici A. Pathogenesis of endometriosis. Obstet Gynecol Clin North Am 2003;30:41-61.

9. Hayes EC, Rock JA. COX-2 inhibitors and their role in gynecology. Obstet Gynecol Surv 2002;57:768-80.

10. Olive DL. Medical therapy of endometriosis. Semin Reprod Med 2003;21:209-22.

11. Kappou D, Matalliotakis M, Matalliotakis I. Medical treatments for endometriosis. Minerva Ginecol 2010;62:415-32.

12. Surrey ES. Gonadotropin-releasing hormone agonist and addback ther-apy: what do the data show? Curr Opin Obstet Gynecol 2010;22:283-8.

13. Ioffe OB, Zaino RJ, Mutter GL. Endometrial changes from short-term therapy with CDB-4124, a selective progesterone receptor modulator. Mod Pathol 2009;22:450-9.

14. Madauss KP, Grygielko ET, Deng SJ, et al. A structural and in vitro characterization of asoprisnil: a selective progesterone receptor modulator. Mol Endocrinol 2007;21:1066-81.

15. Kettel LM, Murphy AA, Mortola JF et al. Endocrine responses to long-term administration of the antiprogesterone RU486 in patients with pelvic endometriosis. Fertil Steril 1991;56:402-7.

16. Kettel LM, Murphy AA, Morales AJ et al. Clinical efficacy of the antiprogesterone RU486 in the treatment of endometriosis and uterine fibroids. Hum Reprod 1994; 9:116-20.

17. Kettel LM, Murphy AA, Morales AJ, et al. Treatment of endometriosis with the antiprogesterone mifepristone (RU486). Fertil Steril 1996;65:23-8.

18. Wang XL, Cheng WJ, Dai HH et al. ERB-041, a selective ERbagonist, inhibits iNOS in LPS activated peritoneal macrophages of endometriosis via suppression of NF-kB. Mol Immunol 2009;46:2413-8.

19. Harris HA, Bruner-Tran KL, Zhang $X$ et al. A selective estrogen receptor-beta agonist causes lesion regression in an experimentally induced model of endometriosis. Hum Reprod 2005;20:936-41.

20. Stratton P, Sinaii N, Segars J, et al. Return of chronic pelvic pain from endometriosis after raloxifene treatment: a ran-domized controlled trial. Obstet Gynecol 2008;111:88-96.

21. Tabibzadeh $S$. The signals and molecular pathways involved in human menstruation, a unique process of tissue destruction and remodelling. Mol Hum Reprod 1996;2:77-92.

22. Braun DP, Ding J, Dmowski WP. Peritoneal fluid-mediated enhancement of eutopic and ectopic endometrial cell proliferation is dependent on tumor necrosis factor-alpha in women with endometriosis. Fertil Steril 2002;78:727-32.
23. D' Hooghe TM, Cuneo S, Nugent N, et al. Recombinant human TNF binding protein-1 ( $\mathrm{r}-\mathrm{h}$ TBP-1) inhibits the development of endometriosis in baboons: a prospective randomized, placebo- and drug-controlled study. Fertil Steril 2001;76-81.

24. Balasch J, Creus M, Fabregues F, et al. Pentoxifylline versus placebo in the treatment of infertility associated with minimal or mild endometriosis: a pilot randomized clinical trial. Hum Reprod 1997; 12: 2046-50.

25. Yildirim G, Attar R, Ficicioglu C, et al. Etanercept causes regression of endometriotic implants in a rat model. Arch Gynecol Obstet 2011;283:1297-302.

26. Islimye $M$, Kilic $S$, Zulfikaroglu $E$, et al. Regression of endometrial autografts in a rat model of endometriosis treated with etanercept. Eur J Obstet Gynecol Reprod Biol 2011; 159:184-9.

27. Barrier FB, Bates GW, Leland MM, et al. Efficacy of antitumor necrosis factor therapy in the treatment of spontaneous endometriosis in baboons. Fertil Steril 2004;81:775-9.

28. Falconer H, Mwenda JM, Chai DC, et al. Treatment with anti-TNF monoclonal antibody $(\mathrm{c} 5 \mathrm{~N})$ reduces the extent of induced endometriosis in the baboon. Hum Reprod 2006;21: 1856-62.

29. Falconer H, Mwenda JM, Chai DC, et al. Effects of antiTNF-mAb treatment on pregnancy in baboons with induced endometriosis. Fertil Steril 2008;89: 1537-45.

30. González-Ramos R, Van Langendonckt A, Defrère $S$, et al. Involvement of the nuclear factor- $\kappa \mathrm{B}$ pathway in the pathogenesis of endometriosis. Fertil Steril 2010; 94: 1985-94.

31. ZhangJJ, Xu ZM, Zhang CM, et al. Pyrrolidine dithiocarbamate inhibits nuclear factor-kB pathway activation and regulates adhesion, migration, invasion and apoptosis of endometriotic stromal cells. Mol Hum Reprod 2011;17:175-81.

32. Nasu K, NishidaM, Ueda T, et al. Application of the nuclear factor-kB inhibitor BAY 11-7085 for the treatment of endometriosis: an in vitro study. Am J Phisiol Endocrinol Metab 2007;293:16-23.

33. Kim JH, Yang YI, Lee KT, et al. Costunolide induces apoptosis in human endometriotic cells through inhibition of the prosurvival Akt and nuclear factor kappa B signaling pathway. Biol Pharm Bull 2011;34:580-5.

34. Piotrowski PC, Kwintkwiewicz J, Rzepczynska IJ, et al. Statins inhibit growth of human endometrial stromal cells independently of cholesterol availability. Biol Reprod 2006;75:107-11.

35. Skaletz-Rorowski A, Walsh K. Statin therapy and angiogenesis. Curr Opin Lipidol 2003;14:599-603.

36. Esfandiari N, Khazaei M, Ai J, et al.Effect of a statin on an in vitro model of endometriosis. Fertility and Sterility 2007 Feb; $87: 257-62$.

37. Vincent L, Chen W, Hong T, et al. Inhibition of endothelial cell migration by cerivastatin, an HMG-CoA reductase inhibitor: contribution to its anti-angiogenic effect. FEBS Lett 2001;495:159-66. 
38. Nasu K, Yuge A, Tsuno A, et al. Simvastatin inhibits the proliferation and the contractility of human endometriotic stromal cells: a promising agent for the treatment of endometriosis. Fertil Steril 2009; 92:2097-9.

39. Sharma I, Dhawan V, Mahajan N,et al. In vitro effects of atorvastatin on lipopolysaccharide-induced gene expression in endometriotic stromal cells. Fertil Steril 2010; 94:1639-46.

40. Yilmaz B, Ozat M, Kilic S, et al. Atorvastatin causes regression of endometriotic implants in a rat model. Reprod Biomed Online 2010;20:291-9.

41. Guney M, Oral B, Karahan N, et al. Regression of endometrial explants in a rat model of endometriosis treated with melatonin. Fertil Steril 2008;89: 934-42.

42. Yildirim G, Attar R, Ozkan F, et al. The effects of letrozole and melatonin on surgicallyinduced endometriosis in a rat model:a preliminary study. Fertility and Sterility 2010; 93: 1787-92.

43. Paul S, Sharma AV, Mahapatra PD, et al. Role of melatonin in regulating matrix metalloproteinase- 9 via tissue inhibitors of metalloproteinase-1 during protection against endometriosis. J Pineal Res 2008;44:439-49.

44. Koc O, Gunduz B, Topcuoglu A, et al. Effects of pinealectomy and melatonin supplementation on endometrial explants in a rat model. Eur J Obstet Gynecol Reprod Biol 2010;153:72-6.

45. New L, Han J. The p38 MAP kinase pathway and its biological function. Trends Cardiovasc Med 1998;8:220-228.

46. Zhou WD, Yang HM, Wang Q, et al. SB203580, a p38 mitogenactivated protein kinase inhibitor, suppresses the development of endometriosis by down-regulating proinflammatory cytokines and proteolytic factors in a mouse model. Hum Reprod 2010;25: 3110-6.

47. Yoshino O, Osuga Y, Koga K, et al. FR 167653, a p38 mitogenactivated protein kinase inhibitor, suppresses the development of endometriosis in a murine model. J Reprod Immunol 2006;72:85-93.

48. Garzetti GG, Ciavattini A, Provinciali M, et al. Natural killer activity in stage III and IV endometriosis: impaired cytotoxicity and retained lymphokine responsiveness of natural killer cells. Gynecol Endocrinol. 1995; 9:125-30.

49. D’Hooghe TM, Hill JA. Endometriosis. In: Berek JS, ed. Novak's gynecology. 13th ed. Philadelphia: Lippincott Williams and Wilkins, 2002; p. 931-72.

50. Itoh $\mathrm{H}$, Sashihara $\mathrm{T}$, Hosono $\mathrm{A}$, et al. Interleukin-12 inhibits development of ectopic endometriotic tissues in peritoneal cavity via activation of $\mathrm{NK}$ cells in a murine endometriosis model. Cytotechnology 2011;63:133-41.

51. Altintas D, Kokcu A, Kandemir B, et al. Efficacy of imiquimod, an immunomodulatory agent, on experimental endometriosis. Fertil Steril 2008;90:401-5.

52. Aytan H, Caglar P, UygurD, etal.Effect of theimmunomodulator leflunomide on the induction of endometriosis in an experimental rat model. Fertil Steril 2007;87:698-701.

53. Ocal G, Kokcu A, Cetinkaya MB, et al.Efficacy of levamisole on experimental endometriosis. Int J Gynaecology Obstet 2007;99:38-42.
54. Ceyhan S.T, Onguru O., Fidan U.et al. Comparison of aromatase inhibitor (letrozole) and immunomodulators (infliximab and etanercept) on the regression of endometriotic implants in a rat model. Eur J Obstet Gynecol Reprod Biol 2011;154: 100-4.

55. Leconte M, Nicco C, Ngo C, et al. The mTOR/AKT inhibitor temsirolimus prevents deep infiltrating endometriosis in mice. Am J Pathol 2011;179:880-9.

56. Osteen KG, Yeaman GR \& Bruner-Tran K. Matrix metalloproteinases and endometriosis. Seminars in Reproductive Medicine 2003; 21: 155-163.

57. Mori T, Yamasaki S, Masui F, et al. Suppression of the development of experimentally induced uterine adenomyosis by a novel matrix metalloproteinase inhibitor, ONO-4817, in mice. Exp Biol Med (Maywood) 2001;226:429-33.

58. Stilley JA, Birt JA, Nagel SC,et al.. Neutralizing TIMP1 restores fecundity in a rat model of endometriosis and treating control rats with TIMP1 causes anomalies in ovarian function and embryo development. Biol Reprod 2010;83:185-94.

59. Harada M. Cell Proliferation and apoptosis: detection of apoptosis in human endometriotic tissues. Mol Hum Reprod 1996; 2:307-15.

60. Meresman GF. Apoptosis and expression of Bcl-2 and Bax in eutopic endometrium from women with endometriosis. Fertil Steril 2000;74:760-6.

61. Selam B. Extracellular matrix-dependent regulation of Fas ligand expression in human endometrial stromal cells. Biol Reprod 2002;66:1-5.

62. Lin Y-J. Neutrophils and macrophages promote angiogenesis in the early stage of endometriosis in a mouse model. Endocrinology 2006; 147:1278-86.

63. Fauvet R. Expression of apoptosis-related proteins in endometriomas and benign and malignant ovarian tumours. Virchows Arch 2003;443:38-43.

64. Collett GP, Campbell FC. Curcumin induces c-jun N-terminal kinasedependent apoptosis in HCT116 human colon cancer cells. Carcinogenesis 2004;25:2183-9.

65. Jana S, Paul S, Swarnakar S. Curcumin as anti-endometriotic agent: implication of MMP-3 and intrinsic apoptotic pathway. Biochem Pharmacol 2012;83:797-804.

66. Taylor RN, Lebovic DI, Mueller MD. Angiogenic factors in endometriosis. Ann N Y Acad Sci 2002;955:89-100.

67. Donnez J, Smoes P, Gillerot $S$, et al. Vascular endothelial growth factor (VEGF) in endometriosis. Hum Reprod. 1998;13:168690.

68. Taylor RN, Mueller MD. Anti-angiogenic treatment of endometriosis: biochemical aspects. Gynecol Obstet Invest 2004;57:54-6.

69. Tabruyn SP, Griffioen AW. Molecular pathways of angiogenesis inhibition. Biochem Biophys Res Commun. 2007; 355:1-5.

70. Becker CM1, Sampson DA, Rupnick MA, et al. Endostatin inhibits the growth of endometriotic lesions but does not affect fertility. Fertil Steril 2005;84: 1144-55.

71. Whitworth A. Endostatin: are we waiting for Godot? J Natl Cancer Inst 2006; 98:731-3. 
72. Veitonmäki N, Cao R, Wu LH, et al. Endothelial cell surface ATP synthase-triggered caspase-apoptotic pathway is essential for k1-5-induced antiangiogenesis. Cancer Res 2004; 64:367986.

73. Chen YH, Wu HL, Li C, et al. Anti-angiogenesis mediated by angiostatin $\mathrm{K} 1-3, \mathrm{~K} 1-4$ and $\mathrm{K} 1-4.5$. Involvement of $\mathrm{p} 53$, FasL, AKT and mRNA deregulation. Thromb Haemost 2006; 95:668-77.

74. Dabrosin C, Gyorffy S,Margetts P, et al. Therapeutic effect of angiostatin gene transfer in a murine model of endometriosis. Am J Pathol 2002;161:909-18.

75. Hazzard TM, Rohan RM, Molskness TA, et al. Injection of antiangiogenic agents into the macaque preovulatory follicle: disruption of corpus luteum development and function. Endocrine 2002;17:199-206.

76. Beerepoot LV, Witteveen EO, Groenewegen G, et al. Recombinant human angiostatin by twice-daily subcutaneous injection in advanced cancer: a pharmacokinetic and longterm safety study. Clin Cancer Res 2003; 9:4025-33.

77. Nap AW, Dunselman GA, Griffioen AW et al. Angiostatic agents prevent the development of endometriosis-like lesions in the chicken chorioallantoic membrane. Fertil Steril 2005; 83:793-5.

78. Gómez R, Abad A, Delgado F, et al. A.Effects of hyperprolactinemia treatment with the dopamine agonist quinagolide on endometriotic lesions in patients with endometriosis-associated hyperprolactinemia. Fertil Steril 2011;95:882-8

79. Leitao VM, Moroni RM, Seko LM, et al.Cabergoline for the prevention of ovarian hyperstimulation syndrome: systematic review and meta-analysis of randomized controlled trials. Fertil Steril 2014;101:664-75.

80. Herbst RS, Madden TL, Tran HT, et al. Safety and pharmacokinetic effects of TNP-470, an angiogenesis inhibitor, combined with paclitaxel in patients with solid tumors: evidence for activity in non-small-cell lung cancer. J Clin Oncol 2002; 20:4440-7.

81. Laschke MW, Elitzsch A, Scheuer C,et al..Rapamycin induces regression of endometriotic lesions by inhibiting neovascularization and cell proliferation. $\mathrm{Br} \mathrm{J}$ Pharmacol 2006;149:137-44.

82. Laschke MW, Elitzsch A, Vollmar B,et al. Combined inhibition of vascular endothelial growth factor (VEGF), fibroblast growth factor and platelet-derived growth factor, but not inhibition of VEGF alone, effectively suppresses angiogenesis and vessel maturation in endometriotic lesions. Hum Reprod 2006; 21:262-8.

83. Pritts EA, Zhao D, Ricke E,et al. PPAR-gamma decreases endometrial stromal cell transcription and translation of RANTES in vitro. J Clin Endocrinol Metab 2002;87:1841-4.

84. Fan W, Yanase T, Morinaga $\mathrm{H}$, et al. Activation of peroxisome proliferator-activated receptor-gamma and retinoid $\mathrm{X}$ receptor inhibits aromatase transcription via nuclear factor-kappaB. Endocrinology 2005; 146:85-92.
85. Lebovic DI, Mwenda JM, Chai DC, et al. T.PPAR-gamma receptor ligand induces regression of endometrial explants in baboons: a prospective, randomized, placebo- and drugcontrolled study. Fertil Steril 2007;88:1108-19.

86. Moravek MB, Ward EA, Lebovic DI. Thiazolidinediones as therapy for endometriosis: a case series. Gynecol Obstet Invest. 2009;68:167-70.

87. Onalan G, Zeyneloglu HB, Bayraktar N. Fenofibrate causes regression of endometriotic implants: a rat model. Fertil Steril 2009;92:2100-2.

88. Takemura Y, Osuga Y, Yoshino O, et al. Metformin suppresses interleukin (IL)-1beta-induced IL-8 production, aromatase activation, and proliferation of endometriotic stromal cells. J Clin Endocrinol Metab 2007; 92:3213-8.

89. Oner G, Ozcelik B, Ozgun MT, et al. The effects of metformin and letrozole on endometriosis and comparison of the two treatment agents in a rat model. Hum Reprod 2010; 25:932-7.

90. Yilmaz B, Sucak A, Kilic S, et al. Metformin regresses endometriotic implants in rats by improving implant levels of superoxide dismutase, vascular endothelial growth factor, tissue inhibitor of metalloproteinase-2, and matrix metalloproteinase-9. Am J Obstet Gynecol 2010;202:368.

91. Foda AA, Aal I. Metformin as a new therapy for endometriosis, its effects on both clinical picture and cytokines profile. MEFSJ 2012;17: 262-7.

92. Dechaud H, Witz CA, Montoya-Rodriguez IA, et al. Mesothelial cell associated hyaluronic acid promotes adhesion of endometrial cells to mesothelium. Fertil Steril 2001; 76:1012-8.

93. Hasegawa A, Yoshino O, Osuga Y, et al. Hyaluronic acid reagent supressed endometriotic lesion formation in Mouse model. Fertil Steril 2010;93:2757-9.

94. Windmeier C, Gressner AM. Pharmacological aspects of pentoxifylline with emphasis on its inhibitory actions on hepatic fibrogenesis. Gen Pharmacol 1997;29:181-96.

95. Mohammadzadeh A, Heidari M, Soltanghoraee $\mathrm{H}$, et al. Evaluation of the effect of pentoxifylline on white blood cell count in serum and peritoneal fluid in female rats with endometriosis. J Obstet Gynaecol Res 2008;34:307-13.

96. Alborzi S, Ghotbi S, Parsanezhad ME, et al. Pentoxifylline therapy after laparoscopic surgery for diferent stages of endometriosis: a prospective, double-blind, randomized, placebo-controlled study. J Minim Invasive Gynecol 2007; 14:54-8.

97. Szczepańska M, Koźlik J, Skrzypczak J, et al. Oxidative stress may be a piece in the endometriosis puzzle. Fertil Steril. 2003; 79:1288-93.

98. Kavtaradze ND, Dominguez CE, Rock JA, et al. Vitamin E and C supplementation reduces endometriosis related pelvic pain. Fertil Steril 2003;161:189-95.

99. Pittaluga E, Costa G, Krasnowska E, et al. More than antioxidant: $\mathrm{N}$-acetyl-L-cysteine in a murine model of endometriosis. Fertil Steril 2010;94:2905-8. 
100. Wu Y, Guo SW. Histone deacetylase inhibitors trichostatin A and valproic acid induce cell cycle arrest and p21 expression in immortalized human endometrial stromal cells. Eur J Obstet Gynecol Reprod Biol 2008;137:198-203.

101. Imesch P, Fink D, Fedier A.Romidepsin reduces histone deacetylase activity, induces acetylation of histones, inhibits proliferation, and activates apoptosis in immortalized epithelial endometriotic cells. Fertil Steril 2010;94:2838-42.

102. Richon VM, Sandhoff TW, Rifkind RA, et al.Histone deacetylase inhibitor selectively induces p21WAF1 expression and gene-associated histone acetylation. Proc Natl Acad Sci U S A 2000;97:10014-9.

103. Liu M, Liu X, Zhang Y, et al. Valproic acid and progestin inhibit lesion growth and reduce hyperalgesia in experimentally induced endometriosis in rats. Reprod Sci 2012; 19:360-73.
104. Liu X, Guo SW. A pilot study on the off-label use of valproic acid to treat adenomyosis. Fertil Steril 2008; 89:246-50.

105. Chen Y, Chen C, Shi S, et al. .Endometriotic implants regress in rat models treated with puerarin by decreasing estradiol level. Reprod Sci. 2011; 18:886-91.

106. Laschke MW, Schwender C, Scheuer C, et al. Epigallocatechin 3-gallate inhibits estrogen-induced activation of endometrial cells in vitro and causes regression of endometriotic lesions in vivo. Hum Reprod. 2008;23:2308-18.

107. Xu H, Lui WT, Chu CY, et al. Anti-angiogenic effects of green tea catechin on an experimental endometriosis mouse model. Hum Reprod 2009; 24:608-18. 